\title{
15. Heterogeneity of Acetylcholine Receptor Molecules on the Surface of Clonal Muscle Cells
}

\author{
By Hiroyuki SugIYAMA \\ Laboratory of Membrane Biology, National Institute for \\ Physiological Sciences, Okazaki 444 \\ (Communicated by Yasuji Katsuki, M. J. A., Feb. 13, 1979)
}

At the neuromuscular junction, skeletal muscles exhibit specially differentiated properties : (1) Their sensitivity to acetylcholine (ACh) is very high. (2) ACh-receptor found at the junction is electrophysiologically and biochemically different from that found at extrajunctional regions: its open time is shorter, ${ }^{1)}$ and its isoelectric point is lower ${ }^{2)}$ than those of extrajunctional receptor. (3) Junctional acetylcholinesterase is of higher oligomeric form (sedimentation coefficient $16 \mathrm{~s})$ than the enzyme found at regions other than the junction. ${ }^{3)}$

Some of these properties, however, are reproduced by muscle cells cultured in vitro in the absence of neurons. The cells develop surface areas with high sensitivity to ACh or "hot spots", ${ }^{4), 5)}$ and synthesize acetylcholinesterase with sedimentation coefficient $16 \mathrm{~s} .{ }^{6}$ It is thus of great interest to study if the muscle cells in culture can synthesize ACh-receptor of junctional type.

In the present study, we analysed ACh-receptor molecules extracted from myogenic clonal cells G8-1 by means of isoelectric focusing technique. The results suggested the presence of at least two types of receptor on the surface of the muscle cells which differ in the isoelectric points.

The G8-1 clonal skeletal muscle cell line was obtained ${ }^{6)}$ by recloning a mouse cell line G8. The cells were cultured essentially as described previously. $\left.{ }^{6}\right) \quad \alpha$-Bungarotoxin $(\alpha \mathrm{BT})$ was purified and iodinated with ${ }^{125} \mathrm{I}$ according to the method of Vogel et al. ${ }^{5)}$ Both mono- and diiodo species were used. ACh-receptor was labeled by incubating cells with $10-15 \mathrm{nM}{ }^{125} \mathrm{I}-\alpha \mathrm{BT}$ in Dulbecco's phosphatebuffered saline containing $2 \mathrm{mg}$ bovine serum albumin $/ \mathrm{ml}$ at $36^{\circ} \mathrm{C}$ for 30-60 min, and was extracted by dissolving with $2-3 \%$ Triton $\mathrm{X}-100$ for $40-60 \mathrm{~min}$ in ice and centrifuging at $48,000 \times \mathrm{g}$ for $60 \mathrm{~min}$.

ACh-receptor- ${ }^{125} \mathrm{I}-\alpha \mathrm{BT}$ complex thus extracted was analysed by isoelectric focusing using LKB Multiphor apparatus. Horizontal flat beds $(10 \times 24 \mathrm{~cm})$ of granulated gels $(4 \mathrm{~g}$ LKB Ultrodex per tray) were used as stabilizing media. The final solution contained in gels was $1.3 \%$ Ampholine $\mathrm{pH} 5$ to 8, 0.7\% Ampholine $\mathrm{pH} 4$ to 6, and 2.0\% 
Triton X-100. Focusing was performed at $10^{\circ} \mathrm{C}$ for 15 to $18 \mathrm{hrs}$ with a maximum voltage of 1500 volts applied across the length. Immediately after the run, the gel bed was devided into 30 zones across the $\mathrm{pH}$ gradient. Each zone was collected and counted for ${ }^{125} \mathrm{I}$, then mixed with $2 \mathrm{ml}$ water and the $\mathrm{pH}$ measured at room temperature.

When intact myotubes are incubated with ${ }^{125} \mathrm{I}-\alpha \mathrm{BT}$ in a culture plate, only ACh-receptor on the cell surface is labeled. ${ }^{7)}$ In Fig. 1 is

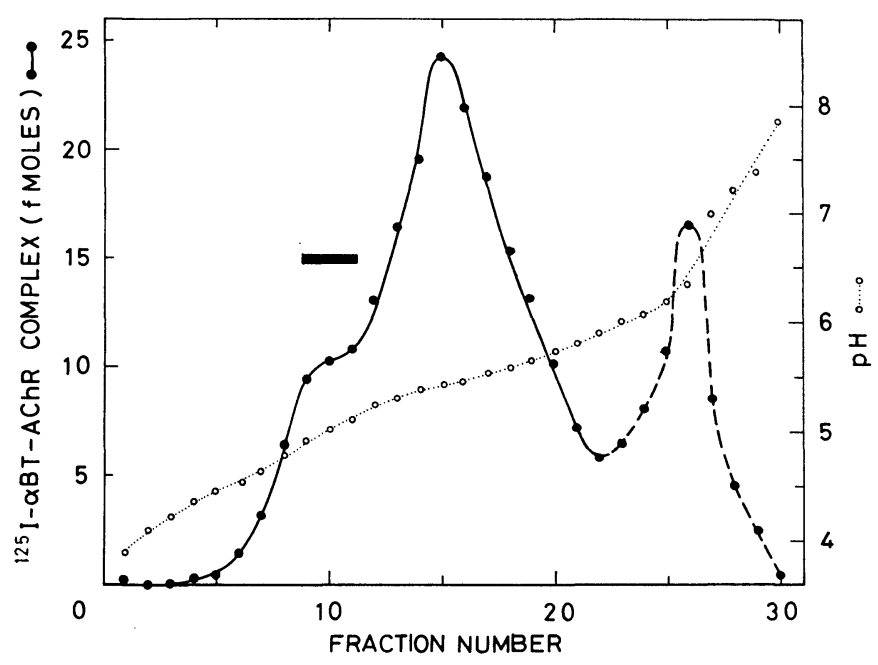

Fig. 1. Isoelectric focusing analysis of G8-1 muscle cell surface acetylcholine receptor $(\mathrm{AChR})$ labeled with ${ }^{125} \mathrm{I}-\alpha$-bungarotoxin $\left({ }^{125} \mathrm{I}-\alpha \mathrm{BT}\right)$. The heavy bar indicates the fractions pooled and submitted to re-focusing, the result of which is shown in Fig. 2 .

shown a result of isoelectric focusing analysis of the receptor labeled in this manner. The sample was applied in a zone close to the cathodic end (fractions 26 to 28 ), and the radioactivity observed in this region (plotted with a dashed line) is an artifact because of this sample loading: Contaminating particulate fraction or aggregates of the receptor in sample may have been trapped in the gel bed. In fact, in one case the sample was applied at the anodic end of the bed, and no peak was observed in the region of $\mathrm{pH}>6.5$. The majority of receptor- ${ }^{125} \mathrm{I}-\alpha \mathrm{BT}$ complex is focused at $\mathrm{pH}$ 5.4-5.5. However, a shoulder is observed at the acidic side of the main peak, the region of $\mathrm{pH} 4.9$ to 5.0. This pattern is reproducibly observed, and unaffected whether mono- or diiodo- ${ }^{125} \mathrm{I}-\alpha \mathrm{BT}$ was used to label the receptor. When the fractions corresponding to the shoulder (heavy bar in Fig. 1) were pooled and submitted to the re-focusing under the same condition, a distinct peak was observed at $\mathrm{pH} 4.9$ to 5.0 (Fig. 2). These results indicate that 


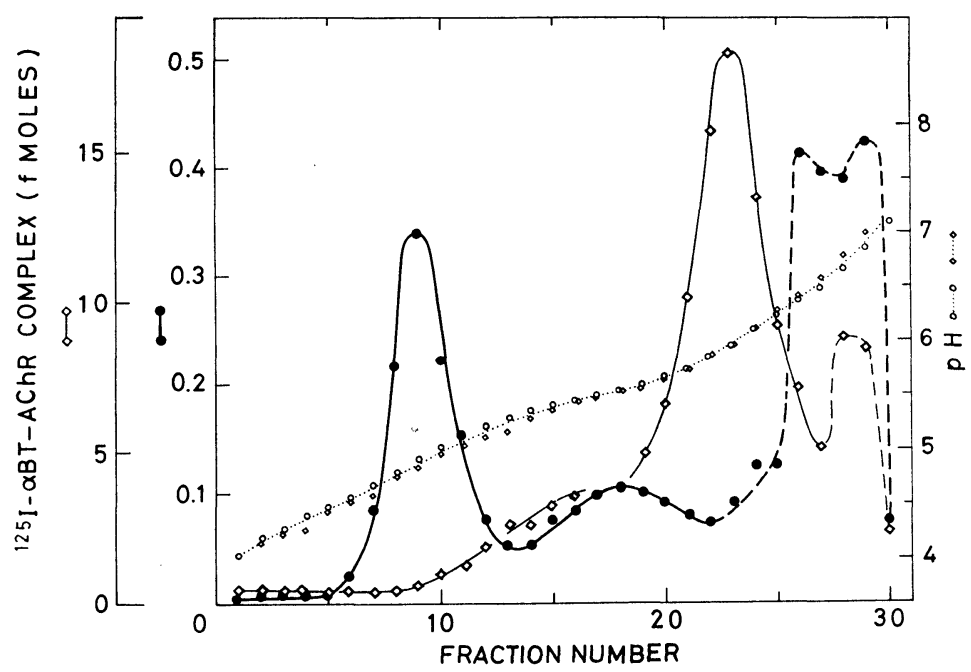

Fig. 2. Isoelectric focusing analyses expressed in a similar manner to Fig. 1. The results of two experiments are shown: 0 , re-focusing of the acidic component of Fig. 1; $\diamond$, muscle cells labeled with ${ }^{125} \mathrm{I}-\alpha \mathrm{BT}$ were homogenized and incubated at $36^{\circ} \mathrm{C}$ for $30 \mathrm{~min}$, then the complex was extracted and submitted to focusing. The $\mathrm{pH}$ gradient of each case is illustrated by corresponding smaller symbols (circles or squares).

the receptor- ${ }^{125} \mathrm{I}-\alpha \mathrm{BT}$ complex extracted under our condition (and therefore most likely the receptor itself) is composed of at least two components whose isoelectric points are approximately 5.0 and 5.4.

ACh-receptor molecules are known to be susceptible to proteolytic digestion and other enzymatic modification. Thus the acidic component of the receptor in Fig. 1 might have been derived from the major one by some modifications during the extraction procedure. In fact, Teichberg and Changeux ${ }^{8)}$ observed two components of AChreceptor with different isoelectric points in electric organ extracts of an electric eel and their catalytic interconversion during the incubation. However, the above mentioned possibility is not very likely in the present case because of the following reasons: (1) After labeling the receptor in intact cells, the entire procedures of preparation of receptor-125 $\mathrm{I}-\alpha \mathrm{BT}$ complex were performed at $0-4^{\circ} \mathrm{C}$ in the media containing protease inhibitors, $0.1 \mathrm{mM}$ phenylmethylsulfonyl fluoride, $0.1 \mathrm{mM}$ benzethonium chloride, and $1.0 \mathrm{mM}$ ethylenediamine tetraacetic acid. ${ }^{9}$ (2) The incubation of cell homogemates at $36^{\circ} \mathrm{C}$ for $30 \mathrm{~min}$ resulted in a shift of the isoelectric point of the major component to a more basic one, approx. 6.0 (Fig. 2). This was the case whether the incubation medium contained $\mathrm{NaCl}$ or $\mathrm{NaF}$, in contrast to the results of Teichberg and Changeux. ${ }^{8)}$ Prolonged storage (several weeks) of cells at $-80^{\circ} \mathrm{C}$ also resulted in a similar basic 
shift of isoelectric point (data not shown). Thus spontaneous or catalytic modification of receptor molecules most likely causes increase rather than decrease in the value of isoelectric point.

The results thus strongly suggest the presence of two forms of ACh-receptor molecules on the muscle cell surface. The isoelectric points of their complexes with ${ }^{125} \mathrm{I}-\alpha \mathrm{BT}$ (approx. 5.0 and 5.4) are very close to those of similar complexes of junctional and extrajunctional ACh-receptors of rat diaphragms, 5.1 and 5.3, respectively. ${ }^{2)}$ Thus we suggest that the cultured muscle cells synthesize ACh-receptor of junctional type as well as extrajunctional type in the complete absence of neuronal effects, as has been observed for acetylcholinesterase. ${ }^{6}$ These two forms of the receptor together with the third form which resulted from some modifications of the native ones may explain the heterogeneous polypeptide composition of purified AChreceptor molecules from calf muscle cells observed by Merlie et al. ${ }^{10}$ )

Some of the experiments reported here were performed in the Radioisotope Center of Hamamatsu University by the help of Professor A. Ichiyama, to whom the author expresses his sincere gratitude.

\section{References}

1) Katz, B., and Miledi, R. (1972): J. Physiol. (London), 224, 665-699.

2) Brockes, J. P., and Hall, Z. W. (1975): Biochemistry, 14, 2100-2106.

3) Hall, Z. W. (1973) : J. Neurobiology, 4, 343-361.

4) Fischbach, G. D., and Cohen, S. A. (1973) : Develop. Biol., 31, 147-162.

5) Vogel, Z., Sytkowski, A. J., and Nirenberg, M. W. (1972) : Proc. Nat. Acad. Sci. U.S.A., 69, 3180-3184.

6) Sugiyama, H. (1977): FEBS Lett., 84, 257-260.

7) Devreotes, P. N., and Fambrough, D. M. (1975) : J. Cell Biol., 65, 335-358.

8) Teichberg, V. I., and Changeux, J. P. (1976) : FEBS Lett., 67, 264-268.

9) Dolly, J. O., and Barnard, E. A. (1975) : FEBS Lett., 57, 267-271.

10) Merlie, J. P., Changeux, J. P., and Gros, F. (1978) : J. Biol. Chem., 253, 2882-2891. 